\title{
Validation of the Revised Ego-Resiliency Scale in a High-Vulnerable Colombian Population*
}

\section{Validación de la Escala de Ego-Resiliencia Revisada en una población colombiana de alta vulnerabilidad}

\section{Giovanni Maria Vecchio ${ }^{a}$}

University of Roma Tre, Italy

ORCID: http://orcid.org/0000-0001-6452-4995

BARBARA BARCACCIA

Università degli Studi Roma Tre, Italy

ORCID: http://orcid.org/0000-0002-3946-481X

PaOlo Raciti

National Institute for the Analysis of Public

Policies, Italy

ORCID: https://orcid.org/0000-0002-2305-6440

Paloma Vivaldi Vera

National Institute for the Analysis of Public

Policies, Italy

ORCID: https://orcid.org/0000-0001-9161-7417

Michela Milioni

National Institute for the Evaluation of the System of

Education and Training (INVALSI), Italy

ORCID: https://orcid.org/0000-0002-1975-262X

a Correspondence author. Email:

giovannimaria.vecchio@uniroma3.it

How to cite: Vecchio, G. M., Barcaccia, B., Raciti, P., Vivaldi, P., \& Milioni, M. (2019). Validation of the Revised EgoResiliency Scale in a High-Vulnerable Colombian Population. Universitas Psychologica, 18(3). 1-13. https:// doi.org.10.11144/Javeriana.upsy18-3.vrer

\begin{abstract}
The ER89 (Block \& Kremen, 1996) is a self-report scale measuring ego-resiliency in community contexts. The present study examined the psychometric properties of a brief version of the ER 89 (ER89-R: Alessandri, Vecchio, Steca, Caprara, \& Caprara, 2007) in a Colombian high-vulnerable population. Participants were 947 young and adults (427 males, 520 females), ranging in age from 16 to 66 years $(M=32.4, S D=$ 11.6), living in fourteen town halls and beneficiaries of four programs for individuals in situations of extreme poverty or victims of violence. CFA supported the presence of the ER second-order factor and two first-order factors, named Optimal regulation (OR) and Openness to life experiences $(\mathrm{OL})$. In addition, results showed full configural invariance of the scales across three age groups (16-25 years, $26-40$ years and over 40 years) and partial strict invariance by gender. The construct validity of the ER89-R was further examined by zero-order correlations and multiple regression analyses: significant and positive association of ER, OR and OL with some relevant indicators of adjustment (self-esteem, optimism, and coping strategies) were found. Important implications for intervention programs aimed at people in disadvantaged contexts are discussed.

Keywords

Ego-resiliency; adjustment; vulnerable individuals; well-being.
\end{abstract}




\section{RESUMEN}

La ER 89 (Block \& Kremen, 1996) es una escala de autoinforme que mide la egoresiliencia en contextos comunitarios. El presente estudio examinó las propiedades psicométricas de una versión breve de la ER 89 ([ER89. R], Alessandri, Vecchio, Steca, Caprara, \& Caprara, 2007) en una población colombiana de alta vulnerabilidad. Los participantes fueron 947 jóvenes y adultos (427 hombres, 520 mujeres), con edades comprendidas entre 16 y 66 años $(\mathrm{M}=32.4, \mathrm{DE}=11.6)$, que vivían en 14 ayuntamientos y beneficiarios de cuatro programas para personas en situaciones de pobreza extrema o víctimas de violencia. El Análisis Factorial Confirmatorio (AFC) apoyó la presencia del factor de segundo orden ER y dos factores de primer orden, denominados Regulación Óptima (RO) y Apertura a las experiencias de la vida (AV). Además, los resultados mostraron una invariancia configuracional completa de las escalas en tres grupos de edad (16-25 años, 26-40 años y más de 40 años) e invariancia estricta parcial por género. La validez de constructo de la ER89-R se examinó más a fondo mediante correlaciones de orden cero y análisis de regresión múltiple: se encontraron asociaciones significativas y positivas de ER, RO y AV con algunos indicadores relevantes de ajuste (autoestima, optimismo y estrategias de afrontamiento). Se discuten importantes implicaciones para los programas de intervención dirigidos a personas en contextos desfavorecidos.

Palabras clave

ego-resiliencia; ajuste; personas vulnerables; bienestar.

Ego-resiliency has been conceptualised as an individual trait or unique quality (Block \& Block, 1980) that helps an individual achieve desirable emotional and social functioning despite exposure to considerable adversity (Alessandri, Zuffianò, Eisenberg, \& Pastorelli, 2017; Masten, Best, \& Garmezy, 1990; Rutter, $1985,2003)$, and refers to the ability to dynamically and appropriately self-regulate, allowing highly resilient people to adapt more quickly to changing circumstances (Block \& Kremen, 1996; Milioni, Alessandri, Eisenberg, \& Caprara, 2016). Thus, it constitutes a protective factor for negative outcomes in important domains of life: resilient individuals are capable of effectively adapting to the various situations, shifting behaviours according to the different circumstances, planning and working for a distant goal (Block \& Block, 2006). Based on Block's work, Benard (2004) considered as crucial characteristics of resilient individuals autonomy, problem solving and social skills, intentions for the future. Individuals who are resilient are capable of successfully adapt to havoc and interference that threaten the ability to function and develop (Masten, 2014). Evidence, in different cultural contexts, show that the development and strengthening of these factors during childhood increases the levels of life satisfaction, career development, job performance, and ability to cope with daily stress in adulthood (Asís, 1999; Bagozzi, Verbecke, \& Gavino, 2003; Steca, Caprara, Tramontano, Vecchio, \& Roth, 2009). Egoresiliency has been found to be directly correlated with several positive developmental outcomes across childhood, from high social competence, attentiveness and flexibility to low externalising and internalising symptoms (Eisenberg, Hernández, \& Spinrad, 2017; Taylor $\&$ Spinrad, 2017). On the contrary, individuals with low ego-resiliency are easily upset by challenging novelties, are slow to adapt, and struggle to bounce back from traumatic or stressful experiences (Block \& Block, 2006; Taylor, Eisenberg, VanSchyndel, Eggum-Wilkens, \& Spinrad, 2014). Furthermore, low Egoresiliency hinders social inclusion, especially in the most vulnerable populations, with difficult living conditions or experiences undermining the lives of individuals (Taylor et al., 2014).

In the context of children involved in armed conflict, ego-resiliency has been described as the children's capacity to bounce back from traumatic events and incidents and thrive into healthy, well-adjusted and socially responsible individuals (Apfel \& Simon, 1996; Shaheen \& Oppenheim, 2016; Shoshani \& Slone, 2016). Trauma exposure, in particular, can have deleterious effect on psychological wellbeing, and ego-resiliency can mediate the adverse effect of the stressors on mental health (Kim, Cho, \& Kim, 2015). In the course of children and adolescents' development, the experience of being a refugee or a displaced person represents a further challenge, to be added to the core tasks of adolescence and to the struggles related to identity development (Betancourt, 2005). 
In displacement situations, education programs can serve a protective function as children are monitored in a more centralised manner and systematic mechanisms for screening their mental and physical health may be established (Bogic, Njoku, \& Priebe, 2015; Crea, 2016; Fazel \& Baillargeon, 2011; Mohamed \& Thomas, 2017). Many social programs in Latin America involving the most vulnerable part of the population seek to strengthen the life skills (World Health Organization [WHO], 1994), considering their importance for individuals' adjustment. In particular, EUROsociAL II (the regional program of European Union in Latin America) that supports public policies and improves levels of social cohesion, has developed an important line of action in order to enhance individuals' life skills (WHO, 1994). Recently, social inclusion programs implemented in Colombia have considered ego-resiliency as one of the protective factors of individuals placed in disadvantaged contexts (Raciti et al., 2015).

\section{Studies on the ER-89}

Block and Kremen (1996) introduced a brief self-report scale (the ER-89) that allows for the measurement of ego-resiliency by subjective self-ratings. The psychometric properties of the ER-89 scale have been investigated in several studies (Alessandri, Vecchio, Steca, Caprara, \& Caprara, 2007; Fonzi \& Menesini, 2005; Letzring, Block, \& Funder, 2005) both in young adults and in adults. In particular, the ER-89 has shown excellent construct validity (Windle, Bennett, $\&$ Noyes, 2011) and good internal reliability (Cronbach's $\alpha=0.76)$ (Block \& Kremen 1996).

Alessandri and colleagues (2007), utilising a revised version of the ER-89 scale, composed of 10 items (ER89-R), identified the construct of ego-resiliency as represented by a second-order factor, defined by two first-order components. These components were identical to those identified in a previous study conducted by Fonzi and Menesini (2005) and labelled ResiliencySelf-Regulation and Resiliency-Openness. The items defining the first factor closely resembled the factors Confident, Optimism and Insight and Warmth identified by Klohnen (1996). The second factor was defined by items similar to those defining the Productive Activity and Skilled Expressiveness factors found by Klohnen (1996). Based on the reported similarities with other investigations, Alessandri et al. (2007) labelled the two first-order factors as Optimal Regulation (OR) and Openness to Life Experience (OL).

Another key-point in research on egoresiliency regards a deeper understanding of gender and age differences. The study of Block and Block (2006) on Euro-American children from early childhood to late adolescence showed that correlations among measures of egoresiliency for males were consistently positive across the years. For females, instead, levels of ego-resiliency in childhood were unrelated to levels of the same construct in adolescence and emerging adulthood, although there was reasonable ordering continuity between timeadjacent assessments. In an Italian sample Vecchione Alessandri, Barbaranelli, and Gerbino (2010) demonstrated that the developmental trajectory of ego-resiliency do not differ between 16 and 20 years both males and females. Finally, only few studies have confirmed the validity of the scale in other cultural contexts (Alessandri, Vecchione, Letzring, \& Caprara, 2012).

\section{Aims of the study}

Building on the prior validation of the ER89-R scale (Alessandri et al., 2007), the present study was designed to examine the applicability of the questionnaire in a highly vulnerable Columbian population. We adopted a second-order model based on two first-order factors, optimal regulation (OR), and openness to life experiences (OL) (Alessandri et al., 2007; Alessandri et al., 2012; Vecchione et al., 2010). First, we examined the factorial structure and the internal consistency of the scale. Second, we tested whether the scale's structure is invariant across gender and age. Third, we analysed the construct validity of the two scales of ER89-R. Namely, this 
refers to the extent to which the Ego-resiliency scale predicted appropriately and distinctively constructs as self-esteem, optimism, and coping strategies.

\section{Method}

\section{Participants}

Participants were included in four national programs promoted in Colombia by the "Prosperidad Social", Department of Colombian National Government: Ingreso Social (participants from 18 to 35 years of age), Jóvenes en Acción (participants from 16 to 24 years of age), Enrútate TU (participants from 30 to 60 years of age; during the application of the assessment tools, this program was converted into Ruta de Inclusión Productiva) and Habilidades para el futuro (participants from 18 to 55 years of age). Beneficiaries of these programs are people in situations of extreme poverty or victims of forced displacement, due to armed conflict or violence related to drug trafficking. Participants in the first three programs lived in eleven different town halls, in order to ensure adequate representation: Florencia, Neiva, Barranquilla, Manizales, Bucaramanga, Medellín, Sincelejo, Cali, Buenaventura, Montería, and Cartagena. Participants in the last program (Habilidades para el futuro) lived in the following three town halls: Pasto, Popayán and Riohacha.

Colombian participants were 947 young and adults (427 males, 520 females), ranging in age from 16 to 66 years $(\mathrm{M}=32.4, \mathrm{SD}=$ 11.6). Their socioeconomic backgrounds varied widely, depending on their geographical position: $76 \%$ were residents of an urban area, and the remaining 23.9\% lived in rural areas. Overall, $21.6 \%$ completed junior high school and $57.8 \%$ completed high school. Only $39.1 \%$ had a job at the time of this study. Overall, 90\% of participants had been victims of forced displacement because of armed conflict or violence related to drug trafficking.
The present investigation was based on data collected as part of a larger study, including vulnerable individuals taking part in the above-mentioned projects. Data were collected with paper-and-pencil self-report questionnaires. The completion of the questionnaire required approximately forty-five minutes to one hour in total. All adult participants signed a written informed consent. Written informed consent was provided by parents of underage participants. A team of data collectors, composed of three trainees in psychology, was present throughout the administration of questionnaires, which took place in the headquarters of the various programs.

\section{Procedure}

The Department of Education of Roma Tre University does not have an ethics committee. However, this study was conducted in accordance with the requirements of privacy and informed consent laid down by Italian law (Law Decree DL-196/2003). Moreover, the study adhered to the latest version of the Declaration of Helsinki revised in Fortaleza (World Medical Association [WMA], 2013) and followed the ethical guidelines of the Italian Association of Psychology (AIP). An Italian researcher and a Colombian researcher were available during administration in all programs, in order to assure comprehension of the items.

\section{Measure}

Ego-resiliency. The ER89-R (Vecchione et al., 2010; Raciti et al., 2015) is a brief inventory composed of 10 items. The psychometric properties of this instrument are presented in Table 1. Cronbach's Alpha was 0.85 for the total scale and 0.78 and 0.75 for Optimal Regulation and Openness to Life Experiences respectively.

Self-esteem. It was assessed with 5 items from the Rosenberg Self-Esteem Scale (Rosenberg, 1965). In general, this scale assesses the extent to which participants believe they possess good qualities, accept their own characteristics, and 
have achieved personal success or experienced failure. For each item, ratings are provided on a 4-point scale ranging from 1 (strongly disagree) to 4 (strongly agree). A sample item is, "I feel that I have a number of good qualities." Internal consistency was good with Cronbach's alpha $=$ 0.87 .

Optimism. It was assessed with the Life Orientation Test (Scheier, Carver, \& Bridges, 1994). We used only six items of 10 total scale (four items were fillers) that measure respondents' expectations about the future. Participants provided their ratings on a 5-point scale ranging from 1 (strongly disagree) to 5 (strongly agree). A sample item is "In uncertain times, I usually expect the best." Internal consistency was satisfying with Cronbach's alpha $=0.70$.

Coping. It was assessed with the COPE questionnaire (Carver, Scheier \& Weintraub, 1989) measuring coping strategies that people use when they face a negative and stressful event. The questionnaire consists of three subscales: Problem-Focussed Coping (to strengthen their efforts to eliminate or reduce stress); EmotionFocussed Coping (to use emotional support based on sympathy and understanding); Disengagement (to use alcohol or other substances with the aim to feel good or to endure stress). We centred our attention on Problem-Focussed Coping with its subscales: Active coping $(\alpha=0.50)$, Planning ( $\alpha$ $=0.73)$, and Use of instrumental support $(\alpha=$ 0.60). The complete questionnaire consists of 45 items rated on a 4 -point scale: $1=$ never; $2=$ rarely; $3=$ sometimes; $4=$ always.

\section{Statistical Analysis}

In order to assess the psychometric properties of the scale in a Columbian population, we conducted a confirmatory factor analysis using Mplus 8.1 (Muthén \& Muthén, 1998-2018), using maximum likelihood (ML) minimisation functions and then, after having established a well-fitting structure, multi-group CFAs were used to test the hypotheses regarding measurement invariance across gender and across age.

We relied on common fit indices to evaluate model to data fit: $\chi^{2}$, comparative fit index (CFI), Tucker-Lewis Index (TLI), root mean square error of approximation (RMSEA), and standardised root mean squared residual (SRMR). Using a chi-square to test for differences among models is frequently used. However, this test is too sensitive for a large sample size $(\mathrm{N}=300)$ (Kline, 2011; MacCallum, Browne, \& Cai, 2006). Owing to this reason, we relied on the principle that the $\chi^{2} / \mathrm{df}$ ratio should be smaller than 3 (Schermelleh-Engel, Moosbrugger, \& Müller, 2003) and made use of the alternative criteria (Akaike Information Criterion [AIC]; see Brown, 2015) to compare models. CFI and TLI values greater than .90 (Kline, 1998), RMSEA values lower than .07 (Browne \& Cudeck, 1993), and SRMR values lower than .08 (Kline, 1998) are considered adequate for good models. Lower values of AIC indicate a better model fit than compared models (Brown, 2015).

In order to test the measurement invariance, a model-fitting process was adopted based on the review by Vandenberg and Lance (2000). Five consecutively more restrictive nested models were tested (Vandenberg, 2002): configural invariance (the same pattern of fixed and free factor loadings across groups), metric invariance (equal factor loadings for items across groups), scalar invariance (the same factor loadings and latent intercepts for the items across group), and strict invariance (imposing an additional constraint on item residual variances). At this regard, we followed Chen's (2007) simulation study, which suggests that $\triangle \mathrm{CFI}, \triangle \mathrm{RMSEA}$, and $\triangle$ SRMR could be used to inspect changes in model fit between nested models. The difference of fit indices between these models should be smaller than .010 for $\triangle \mathrm{CFI}, .015$ for $\triangle \mathrm{RMSEA}$, and .030 for $\triangle$ SRMR in a large sample size $(\mathrm{N}$ = 300) (Chen, 2007). Given that full MI models could not be found, we tested for partial MI. We followed Schwartz and colleagues' (2014) 
suggestion that partial invariance is still tenable if less than half of item are freely estimated.

Finally, we tested the construct and discriminant validity of the ER89- $R$ in a Columbian population. At this regard, we examined the relations of the ER89- $\mathrm{R}$ with measures of adjustment (self-esteem, optimism, and three coping strategies). In particular, we conducted a series of standard multiple regression analyses including Ego-resiliency as predictors and one measure of adjustment as the dependent variable (in total, we examined five regression analyses).

\section{Results}

\section{Descriptive Statistics}

We examined the data for univariate and multivariate variable distributions using the procedure devised by Tabachnick and Fidell (1989). No outlier participants were detected. Table 1 presents the means $(\mathrm{M})$, standard deviations (SD), skewness, and kurtosis parameters for the ER89- $\mathrm{R}$ items. The Keiser Meyer Olking test of sampling adequacy was 0.90. Bartlett's Test of Sphericity was also largely significant.

\section{Table 1}

Descriptive statistics of Items of ER89-R

Questionnaire

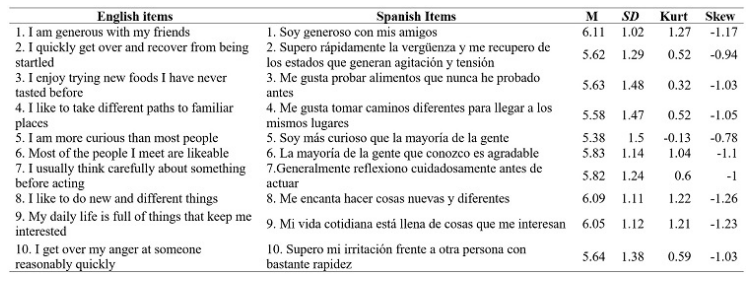

\section{Confirmatory Factor Analysis}

To investigate the stability of the ER89-R factor structure, we ran separate CFAs using the sample covariance matrices. We tested three models: a one-factor model (Model 1), a twocorrelated-factor model (Model 2) and a model with a second order factor (Model 3). The fit indices related to the aforementioned models are reported in Table 2 .

Table 2

Fit Indices for Confirmatory Factor Analysis of the ER89-R scale

\begin{tabular}{|c|c|c|c|c|c|}
\hline Model & $\chi^{2}(d f)$ & CFI & TLI & RMSEA $(90 \% \mathrm{CI})$ & SRMR \\
\hline Model 1 & $371.582(34)$ & 0.88 & 0.85 & $0.1(0.09-0.11)$ & 0.2628823 .8 \\
\hline Model 2 & $191.778(33)$ & 0.94 & 0.93 & $0.07(0.06-0.08)$ & 0.0528646 .0 \\
\hline Model 3 & $182.371(32)$ & 0.95 & 0.93 & $0.07(0.06-0.08)$ & 0.0428638 \\
\hline \multicolumn{6}{|c|}{$\begin{array}{l}\text { Note. Model } 1 \text { refers to one factor model; Model } \\
2 \text { refers to two-correlated-factor model; Model } \\
3 \text { refers to a model with a second order factor; } \\
\text { CFI = Comparative Fit Index; TLI = Tucker- } \\
\text { Lewis Index; RMSEA = Root-Mean-Square Error } \\
\text { of Approximation; CI = Confidence Interval; } \\
\text { SRMR = Standardised Root-Mean-Square } \\
\text { Residual; AIC = Akaike Information Criterion. }\end{array}$} \\
\hline
\end{tabular}

Results showed the presence of a second order factor, because this model fit the data better than the other two models, $\chi^{2} \quad(d f=32 ; N=947)$ $=182.371, p<0.01, \mathrm{CFI}=0.95$, TLI $=.93$, RMSEA $=0.07(\mathrm{CI}=0.06-0.08)$, SRMR $=$ 0.04, confirming Block's theory (Block \& Block, 1980; Block \& Kremen, 1996). All parameters were significant, $\mathrm{p}<0.05$, and all were $>0.30$. Two modification indexes (MI) were reported for the covariation between error items 8 and 7 $(\mathrm{MI}=47.23)$, and 8 and $9(\mathrm{MI}=45.64)$. For identification purposes, we constrained as equal the error variances for the first-order factors $(\psi 1.1$ $=\psi 2.2$ ), fixed the first loading on the secondorder factor (i.e., $\gamma 1.1=1$ ), and estimated the second-order model that presents an identical fit and degrees of freedom as the previous two-factor model (Bollen, 1989; see Figure 1). 
Figure 1

Path diagram of the ER89-R scale

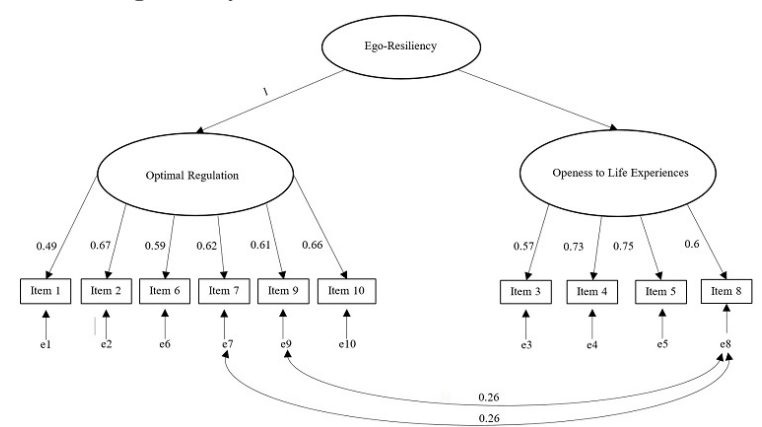

Note. e1-e10 represent error terms. Standardised factor loadings are shown on the straight arrows; error term intercorrelations are shown on the curved arrows. The intercorrelations of the error terms between items 7 and 8 and between 8 and 9 were freed.

\section{Invariance across Gender}

Table 3 shows results of MI analyses across genders for the best-fitting model (a second order factor model). Findings confirmed full configural and metric invariance, indicating that the best-fitting factorial structure was confirmed within males and females. Instead, the full scalar invariance was not supported. At this regard, we found that if the equality constraint was lifted from one item intercept for optimal regulation dimension (Items 7) and one item intercept for openness to life experiences (Item 5), then the partial scalar invariance could be established.

Finally, strict invariance and partial strict invariance were investigated. Analysis showed that if the equality constraint was lifted from one residual variance for optimal regulation dimension (Items 10) and one residual variance for openness to life experiences (Item 3), the partial strict invariance could be supported.

\section{Invariance across age}

Table 4 shows results of MI analyses across three age group (16-25 years, 26-40 years and over 40 years) for the best-fitting model (a second order factor model). Findings confirmed full configural invariance, indicating that the bestfitting factorial structure was confirmed within three age group. The full metric invariance was not supported. At this regard, also the partial metric invariance was not tenable because less than half of intercepts were freely estimated (Schwartz et al., 2014).

\section{Table 3}

Fit Indices for Measurement Invariance across gender

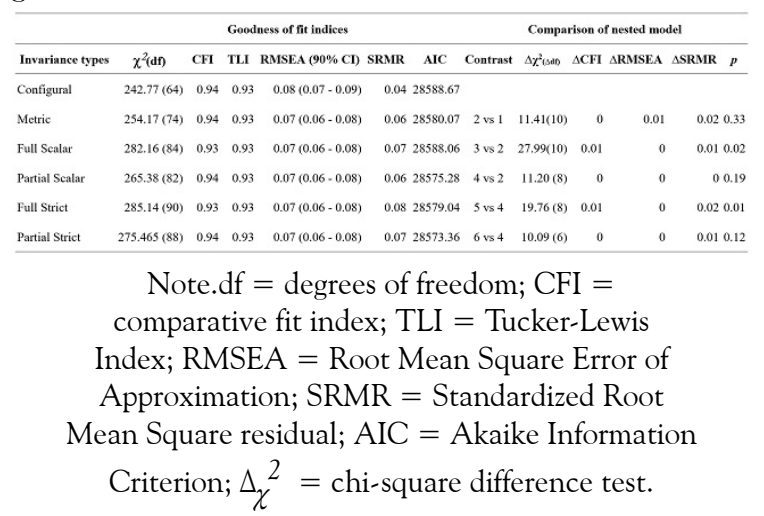

Table 4

Fit Indices for Measurement Invariance across age group

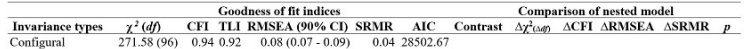

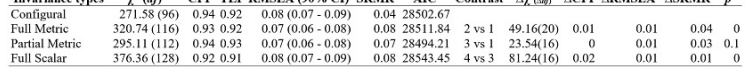

$$
\begin{aligned}
& \text { Note.df }=\text { degrees of freedom; CFI = }
\end{aligned}
$$

\section{Construct validity}

Table 5 contains the zero-order correlations between Ego-resiliency and some relevant indicators of adjustment (self-esteem, optimism, and coping strategies). All variables were highly and positively correlated to each other. The correlations were similar for ER89-R Optimal Regulation and for ER89-R Openness to Life Experiences.

The results of the standard multiple regression (see Table 6) demonstrated that the total (second order) score of ego-resiliency explained between 
$1 \%$ and $52 \%$ of variance in all adjustment outcomes. As expected, this score predicts the outcomes sufficiently well.

Table 5

Zero-order Correlations between Ego-resiliency and Relevant Indicators of Adjustment

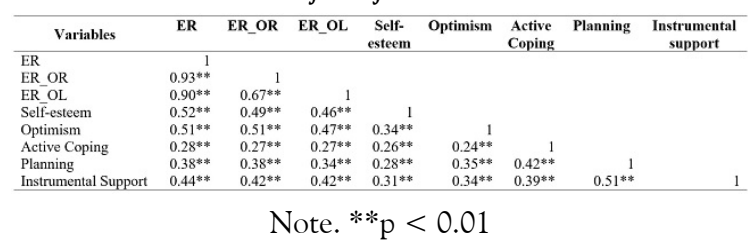

Table 6

Results of Standard Multiple Regression of the Egoresiliency on Relevant Indicators of Adjustment

\begin{tabular}{lcc}
\hline \multirow{2}{*}{ Criterion Variables } & \multicolumn{2}{c}{ Standardized $\boldsymbol{\beta}$} \\
\cline { 2 - 3 } & $\boldsymbol{R}^{\mathbf{2}}$ & $\boldsymbol{R} \boldsymbol{E S}$ \\
\hline Self-esteem & 0.52 & $0.52^{* *}$ \\
Optimism & 0.26 & $0.51^{* *}$ \\
Active Coping & 0.08 & $0.28^{* *}$ \\
Planning & 0.15 & $0.38^{* *}$ \\
Instrumental support & 0.19 & $0.44^{* *}$ \\
\hline
\end{tabular}

Note. $* * p<0.01$.

\section{Discussion}

Although a large amount of studies have analysed the importance of ego-resiliency for individual positive social functioning, little is known about the assessment of this construct. In the present study, we have investigated the dimensionality of the ER89-R scale proposed by Block and Kremen (1996) and revised by Alessandri et al. (2007) in a vulnerable population and have designed its cross-gender and cross-age invariance and its relationship with some adjustment measures.

Our first aim was to test competing CFA models in order to find the best-fitting factorial structure. Prior ER89-R's validation studies, conducted in European samples (Alessandri et al., 2007; Fonzi \& Menesini, 2005), tested a second-order factor solution, and defined by two first-order components. Therefore, we tested and compared three solutions (a one-factor model, a two-correlated-factor model and a model with a second order factor), within a highly vulnerable
Colombian population. Our results confirmed the second order solution, in line with prior validation studies.

The second aim was to use the best-fitting model to test whether MI could be established across sex and across age. Findings of the MI across genders demonstrate full configured, metric invariance, partial scalar invariance and partial strict invariance. First, the establishment of full configured invariance indicates that same items are associated with the same latent factors across sex. Second, the establishment of full metric invariance suggests that factor loadings for all items are consistent across males and females. In relation to scalar and strict invariance, we only found partial MI. Individual factors related to gender differences can affect the intercept and residual variances of items (Chen, 2007; Schwartz et al., 2014), which could suggest that males may conceptualise their behaviours differently compared to females.

In addition, findings of MI across age (late adolescents, young adults and adults) supported full configural and partial metric, indicating that there are considerable differences in the factor loadings, in the item intercepts and in the residual variances item among the three age groups. These results may be affected by differences due to the development stage that individuals are going through.

Finally, after ascertaining the invariance of the ER89-R scale, we focussed on its construct validity. Results showed that Ego-resiliency was highly associated with self-esteem, optimism and the three scales of Problem-focussed Coping (Active Coping, Planning, Use of Instrumental Support), supporting the construct validity. Our results are in line with literature data indicating that ego-resilience is a personal strength that support individuals in effectively coping with stress (Loh, Schutte, \& Thorsteinsson, 2014) and is associated to well-being and optimism: Panchal, Mukherjee and Kumar (2016) found a positive and significant correlation between optimism and resilience. Moreover, the authors found that resilience was a good predictor of well-being. Finally, resilience was negatively correlated with distress (Panchal et al., 2016) 
and positively predicted humility, gratitude and forgiveness (Baldwin, Jackson, Okon, \& Cannon, 2011), variables of effective coping with stressful situations in life and of positive adjustment (Barcaccia, Pallini, Milioni, \& Vecchio, 2018; Barcaccia et al., 2019). Strengthening egoresiliency can help vulnerable individuals to better manage stress and can promote higher levels of adaptive coping. Thus, ego-resilience can be an important asset particularly for vulnerable individuals, who might benefit from programs aimed at promoting this important transversal skill, in order to better cope with stressful situations in life.

From a theoretical point of view, our study is completely in accordance with Block and Block's (1980) theory of personality that defines egoresiliency as a higher-order system. Our study is relevant, as it is the first to support the dimensionality of the ER89- $\mathrm{R}$ in a vulnerable Colombian population. The potential usefulness and applicability of this scale are quite broad. Researchers in the area of self-regulation and related fields could benefit from this brief and reliable instrument that proved to be highly predictive of individual functioning. However, we encourage researchers to use these scales in combination with larger personality inventories (i.e., the Big Five) for a deeper understanding of how ego-resiliency works with other personality characteristics.

A few limitations of the current study should be noted. First, it would be desirable to test the generalisability of our findings across different populations and cultural contexts. However, the Colombian experience is a first step toward the implementation of this instrument in other cultural contexts and laid the foundations for cooperation with other Latin American countries: Chile, Ecuador, Honduras, Peru, and El Salvador (Raciti et al., 2015). Second, all variables were assessed using self-report measures. Future research could benefit from assessing constructs using multiple methods (i.e., clinical interviews, information processing tasks, etc.) and informants (i.e., parents and peers). In addition, future research on protective processes influencing the mental health of children in war must explore contextual factors across the family, community and societal levels (Boyden \& de Berry, 2004; Chatty \& Lewando-Hundt, 2001; Earls \& Carlson, 2001; Macksoud \& Aber, 1996). Finally, this study was based on cross-sectional data and the test-retest reliability has not been computed.

In conclusion, studies on ego-resiliency offer a promising starting point to try to develop intervention projects useful to support the wellbeing of people in disadvantaged contexts. As evidenced by Masten and Wright (2009), there is still much work to do. On one hand, researchers should contribute to increase the knowledge of individual, cultural and contextual differences that may influence the effectiveness of prevention and intervention strategies. On the other hand, the institutions should equip the teachers with internal social policies to improve the positive adaptation of people and to prepare them to deal with the adverse events that may occur in everyone's life. Notwithstanding some limitations, researchers in the area of positive psychology may benefit from the Ego-resiliency scale when evaluating interventions aimed at improving resilience and foster well-being.

\section{References}

Alessandri, G., Vecchio, G. M., Steca, P., Caprara, M. G., \& Caprara, G. V. (2007). A revised version of Kremen and Block's Ego Resiliency Scale in an Italian sample. TPM-Testing, Psychometrics, Methodology in Applied Psychology, 14(3-4), 165-183. Retrieved from https://pdfs.semanticscholar.org/2fb2/ 7dcdb46231756ab173b13e1c8c60b71e2e0 c.pdf

Alessandri, G., Vecchione, M., Caprara, G. V., \& Letzring, T. D. (2012). The Ego Resiliency Scale Revised: A cross-cultural study in Italy, Spain, and the United States. European Journal of Psychological Assessment, 28(2), 139-146. https://doi.org/10.1027/10 $15-5759 / \mathrm{a} 000102$ 
Alessandri, G., Zuffianò, A., Eisenberg, N., \& Pastorelli, C. (2017). The role of ego-resiliency as mediator of the longitudinal relationship between family socio-economic status and school grades. Journal of Youth and Adolescence, 46, 2157-2168. https://doi.org/10.1007/s10964 $-017-0691-7$

Apfel, R. J., \& Simon, B. (1996). Psychosocial interventions for children of war: The value of a model of resiliency. Medicine and Global Survival, 3, A2. Retrieved from https://ippnw.org/ ippnwor1/pdf/mgs 3-apfel-simon.pdf

Asís, F. (1999). ¿De quién se predican las competencias profesionales?: una invitación a su investigación. Revista de Psicología del Trabajo y de las Organizaciones, 15(3), 407-418. Retrieved from https://dialnet.unirioja.es/servlet/artic ulo? codigo $=293291$

Bagozzi, R. P., Verbecke, W., \& Gavino, J. C., Jr. (2003). Culture moderates the selfregulation of shame and its effects on performance: The case of salespersons in the Netherlands and the Philippines. Journal of Applied Psychology, 88, 219-233. h ttps://doi.org/10.1037/0021-9010.88.2.219

Baldwin, D. R., Jackson, D., Okoh, I., \& Cannon, R. L. (2011). Resiliency and optimism: An African American senior citizen's perspective. The Journal of Black Psychology, 37, 24-41. https://doi.org/10.11 77/0095798410364394

Barcaccia, B., Pallini, S., Milioni, M., \& Vecchio, G. M. (2018). Resentment or forgivingness? The assessment of forgiveness in Italian adolescents. Child Indicators Research, 11, 1407-1423. https://doi.org/10.1007/s12187 $-017-9483-6$

Barcaccia, B., Pallini, S., Pozza, A., Milioni, M., Baiocco, R., Mancini, F., \& Vecchio, G. M. (2019). Forgiving adolescents: Far from depression, close to well-being. Frontiers in Psychology, 10(1725), 1-9. https://doi.org/1 $0.3389 /$ fpsyg.2019.01725

Benard, B. (2004). Resiliency: What we have learned. San Francisco, CA: WestEd.
Betancourt, T. S. (2005). Stressors, supports and the social ecology of displacement: Psychosocial dimensions of an emergency education program for Chechen adolescents displaced in Ingushetia, Russia. Culture, Medicine $\mathbb{B}$ Psychiatry, 29, 309-340. https://doi.org/10.1 007/s11013-005-9170-9

Block, J., \& Block, J. H. (2006). Venturing a 30-year longitudinal study. American Psychologist, 61, 315-327. https://doi.org/10 .1037/0003-066X.61.4.315

Block, J. H., \& Block, J. (1980). The role of ego-control and ego-resiliency in the organization of behavior. In W. A. Collins (Ed.), Minnesota symposia on child psychology (Vol. 13, pp. 39-101). Hillsdale, NJ: Erlbaum.

Block, J., \& Kremen, A. M. (1996). IQ and ego-resiliency: Conceptual and empirical connections and separate-ness. Journal of Personality and Social Psychology, 70, 349-361. https://doi.org/10.1037/0022-351 4.70.2.349

Bogic, M., Njoku, A., \& Priebe, S. (2015). Long-term mental health of war-refugees: A systematic literature review. BMC International Health and Human Rights, 15(1), 1-41. https://doi.org/10.1186/s12914 $-015-0064-9$

Boyden, J., \& de Berry, J. (Eds.). (2004). Children and youth on the front line: Ethnography, armed conflict and displacement. New York: Berghahn Books.

Brown, T. A. (2015). Confirmatory factor analysis for applied research ( $2^{\text {nd }}$ ed.). New York: Guilford.

Browne, M. W., \& Cudeck, R. (1993). Alternative ways of assessing model fit. In K. A. Bollen \& J. S. Long (Eds.), Testing structural equation models (pp. 136-162). Newbury Park, CA: Sage.

Bollen, K. A. (1989). Structural equations with latent variables. New York: Wiley.

Carver, C. S., Scheier, M. F., \& Weintraub, J. K. (1989). Assessing coping strategies: A theoretically based approach. Journal of Personality and Social Psychology, 56, 
267-283. https://doi.org/10.1037/0022-351 4.56.2.267

Chatty, D., \& Lewando-Hundt, G. (2001). Children and adolescents in Palestinian households: Living with the effects of prolonged conflict and forced migration (Lesson Learned Report. Special publication of the RSC and ARC, Oxford and Beirut). Oxford: Refugee Studies Centre.

Chen, F. F. (2007). Sensitivity of goodness of fit indexes to lack of measurement invariance. Structural Equation Modeling, 14(3), 464-504. https://doi.org/10.1080/10 705510701301834

Crea, T. M. (2016). Refugee higher education: Contextual challenges and implications for program design, delivery, and accompaniment. International Journal of Educational Development, 46, 12-22. https:// doi.org/10.1016/j.ijedudev.2015.11.005

Earls, F., \& Carlson, M. (2001). The social ecology of child health and well-being. Annual Review of Public Health, 22, 143-166. https://doi.org/10.1146/annurev. publ-health.22.1.143

Eisenberg, N., Hernández, M. M., \& Spinrad, T. L. (2017). The relation of self-regulation to externalizing and internalizing problems. In C. A. Essau, T. H. Ollendick \& S. S. LeBlanc (Eds.), Emotion regulation and psychopathology in children and adolescents (pp. 18-42). Oxford: Oxford University Press.

Fazel, S., \& Baillargeon, J. (2011). The health of prisoners. The Lancet, 377 (9769), 956-965. https://doi.org/10.1016/S0140-67 36(10)61053-7

Fonzi, A., \& Menesini, E. (2005). Strategie di coping e caratteristiche di resilienza in adolescenza. Psicologia Clinica dello Sviluppo, 3, 437-456. https://doi.org/10.1449/21190

Kim, Y. J., Cho, Y.-A., \& Kim, H. A. (2015). A mediation effect of ego resiliency between stresses and mental health of North Korean refugee youth in South Korea. Child and Adolescent Social Work Journal, 32, 481-490. https://doi.org/10.1007/s10560-0 $15-0385-5$
Kline, R. B. (1998). Principles and practice of structural equation modelling. New York: Guilford.

Kline, R. B. (2011). Principles and practice of structural equation modelling ( $3^{\text {rd }}$ ed.). New York: Guilford.

Klohnen, E. C. (1996). Conceptual analysis and measurement of the construct of ego resiliency. Journal of Personality and Social Psychology, 70, 1067-1079. https://doi.org/1 0.1037/0022-3514.70.5.1067

Letzring, T. D., Block, J., \& Funder, D. C. (2005). Ego-control and egoresiliency: Generalization of self-report scales based on personality descriptions from acquaintances, clinicians, and the self. Journal of Research in Personality, 39, 395-422. https://doi.org/10.1016/j.jrp.2004 .06 .003

Loh, J., Schutte, N., \& Thorsteinsson, E. (2014). Be happy: The role of resilience between characteristic affect and symptoms of depression. Journal of Happiness Studies, 15(5), 1125-1138. https://doi.org/10.1007/s 10902-013-9467-2

MacCallum, R. C., Browne, M. W., \& Cai, L. (2006). Testing differences between nested covariance structure models: Power analysis and null hypotheses. Psychological Methods, 11, 19-35. https://doi.org/10.1037/1082-98 9X.11.1.19

Macksoud, M. S., \& Aber, J. L. (1996). The war experiences and psychosocial development of children in Lebanon. Child Development, 67(1), 70-88. https://doi.org/10.1111/j.146 78624.1996.tb01720.x

Masten, A. S. (2014). Ordinary magic: Resilience in development. New York: Guilford.

Masten, A. S., Best, K. M., \& Garmezy, N. (1990). Resilience and development: Contributions from the study of children who overcome adversity. Development and Psychopathology, 2(4), 425-444. https://doi. org/10.1017/S0954579400005812

Masten, A. S., \& Wright, M. O. (2009). Resilience over the lifespan: Developmental perspectives on resistance, recovery, and transformation. In J. W. 
Reich, A. J. Zautra \& J. S. Hall (Eds.), Handbook of adult resilience (pp. 213-237). New York: Guilford.

Milioni, M., Alessandri, G., Eisenberg, N., \& Caprara, G. V. (2016). The role of positivity as predictor of ego-resiliency from adolescence to young adulthood. Personality and Individual Differences, 101, 306-311. ht tps://doi.org/10.1016/j.paid.2016.06.025

Mohamed, S., \& Thomas, M. (2017). The mental health and psychological well-being of refugee children and young people: An exploration of risk, resilience and protective factors. Educational Psychology in Practice, 33(3), 249-263. https://doi.org/10.1080/02 667363.2017 .1300769

Muthén, L., \& Muthén, B. (1998-2018). Mplus user's guide ( $8^{\text {th }}$ ed.). Los Angeles, CA: Muthén \& Muthén.

Panchal, S., Mukherjee, S., \& Kumar, U. (2016). Optimism in relation to wellbeing, resilience, and perceived stress. International Journal of Education and Psychological Research, 5(2), 1-6. Retrieved from https://pdfs.semanticscholar.org/ae6c/ 244ad137bb8a008d20cbec64fa3db235ac8 0.pdf

Raciti, P., Milioni, M., Uribe, L., Vecchio, G. M., Giraldo Villate, C. I., \& Vivaldi Vera, P. (2015). La medicio\#n de las competencias transversales en Colombia: una propuesta metodolo\#gica. Madrid: Programa Eurosocial. Retrieved from http://sia.euroso cial-ii.eu/files/docs/1444897404-DT34.pdf

Rosenberg, M. (1965). Society and the adolescent self-image. Princeton, NJ: Princeton University Press.

Rutter, M. (1985). Resilience in the face of adversity: Protective factors and resistance to psychiatric disorders. British Journal of Psychology, 147, 598-611. https://doi.org/10 $.1192 /$ bjp.147.6.598

Rutter, M. (2003). Genetic influences on risk and protection: Implications for understanding resilience. In S. S. Luthar (Ed.), Resilience and vulnerability: Adaptation in the context of childhood adversities (pp. 489-509). New York: Cambridge University Press.
Scheier, M. F., Carver, C. S., \& Bridges, M. W. (1994). Distinguishing optimism from neuroticism (and trait anxiety, self-mastery, and self-esteem): A reevaluation of the Life Orientation Test. Journal of Personality and Social Psychology, 67 (6), 1063-1078.

Schermelleh-Engel, K., Moosbrugger, H., \& Mu\#ller, H. (2003). Evaluating the fit of structural equation models: Tests of significance and descriptive goodness-offit measures. Methods of Psychological Research Online, 8, 23-74. Retrieved from http://www.stats.ox.ac.uk/ snijders/ mpr_Schermelleh.pdf

Shaheen, M. M., \& Oppenheim, S. (2016). Youth resilience makes a difference in mitigating stress: Teacher mediated school intervention in Bethlehem. Intervention, 14(3), 305-319. Retrieved from https://www.interventionjournal.com /sites/default/files/Youth_resilience_makes _a_difference_in_mitigating.13.pdf

Shoshani, A., \& Slone, M. (2016). The resilience function of character strengths in the face of war and protracted conflict. Frontiers in Psychology, 6, 2016. https://doi.org/10.3389 /fpsyg.2015.02006

Steca, P., Caprara, G. V., Tramontano, C., Vecchio, G. M., \& Roth, E. (2009). Young adults' life satisfaction: The role of selfregulatory efficacy beliefs in managing affects and relationships across time and across cultures. Journal of Social and Clinical Psychology, 28(7), 824-861. https://doi.org/ 10.1521/jscp.2009.28.7.824

Schwartz, S. J., Benet-Martínez, V., Knight, G. P., Unger, J. B., Zamboanga, B. L., Des Rosiers, S. E., . . Szapocznik, J. (2014). Effects of language of assessment on the measurement of acculturation: Measurement equivalence and cultural frame switching. Psychological Assessment, 26, 100-114. https://doi.org/10.1037/a0034 717

Tabachnick, B. G., \& Fidell, L. S. (1989). Using multivariate statistics (2 ${ }^{\text {nd }}$ ed.). New York, NY: Harper \& Row. 
Taylor, Z. E., Eisenberg, N., VanSchyndel, S. K., Eggum-Wilkens, N. D., \& Spinrad, T. L. (2014). Children's negative emotions and ego-resiliency: Longitudinal relations with social competence. Emotion, 14, 397-406. h ttps://doi.org/10.1037/a0035079

Taylor, Z. E., \& Spinrad, T. L. (2017). Developmental tools that build social and emotional competence in school: A focus on effortful control and ego-resiliency. In M. A. Warren \& S. I. Donaldson (Eds.), Toward a positive psychology of relationships: New directions in theory and research (pp. 119-144). Santa Barbara, CA: Praeger/ ABC-CLIO.

Vandenberg, R. J. (2002). Toward a further understanding of an improvement in measurement invariance methods and procedures. Organizational Research Methods, 5, 139-158. https://doi.org/10.117 7/1094428102005002001

Vandenberg, R. J., \& Lance, C. E. (2000). A review and synthesis of the measurement invariance literature: Suggestions, practices, and recommendations for organizational research. Organizational Research Methods, 3, 4-69. https://doi.org/10.1177/109442810 031002

Vecchione, M., Alessandri, G., Barbaranelli, C., \& Gerbino, M. (2010). Stability and change of ego resiliency from late adolescence to young adulthood: A multiperspective study using the ER89-R Scale. Journal of Personality Assessment, 92, 1-10. https://doi. org/10.1080/00223891003670166

Windle, G., Bennett, K. M., \& Noyes, J. (2011). A methodological review of resilience measurement scales. Health and Quality of Life Outcomes, 9, 1-18. https://doi.org/10.1 186/1477-7525-9-8

World Health Organization (1994). Life Skills Education in Schools. Geneva: WHO.

World Medical Association (2013). WMA Declaration of Helsinki - Ethical Principles for Medical Research Involving Human Subjects (2013). Retrieved from: https://www.wma.net/policies-post/w ma-declaration-of-helsinki-ethical-principl es-for-medicalresearch-involving-human-s ubjects/, Accessed date: June 11th 2017.

\section{Notes}

* Research article. 